\title{
A Corpus Stylistic Analysis of Abulhawa's the Blue between Sky and Water
}

\author{
* Zahoor Hussain \\ ** Samiullah Khan \\ *** Muhammad Ajmal, Assistant Professor (Corresponding Author)
}

\begin{abstract}
Palestinian literature received significance after Nakba (1948 Palestine-Israel war) and Naksa (1967 Arab-Israel war) and it laid an impact on Palestinian writers and there emerged a new form of literature called Palestinian American literature which got recognition in the 1990s internationally. After Nakba and Naksa many Palestinian families migrated to America. These Palestinians wrote literature in English that is called Palestinian-American literature. The aim of the stylistic analysis of Abulhawa's work to trace out how the writer constructs reality through lexical categories. This thesis also analyzes the work of Palestinian-American writer Abulhawa's novel, The Blue between Sky and Water, and focuses specifically on how the writer achieves her aims. At the same time, this stylistic analysis of The Blue between Sky and Water shed light on the use of Arabic words in English fiction which represent the culture and identity of the Palestinian nation. It explores the dilemma of Palestine that they become a foreigner in their native land. The researcher employed a mixed-method approach to conduct the present study. The researcher used Corpus stylistics tools to analyze the novel. The researcher traced around 6288 concrete nouns and 1634 abstract nouns from the sample respectively. The extensive use of concrete nouns showed that the main purpose of the writer was to get homeland and this piece of writing was not only art for art sake rather art for life's sake. The researcher traced out around 1400 adjectives from the sample of study.
\end{abstract}

Keywords: Corpus, Stylistic Analysis, Palestinian Literature, Lexis Introduction

The present study analyzes Abulhawa's novel The Blue between Sky and Water stylistically. The researcher analyzes how the writer deviates from the standard syntactical patterns and how she use linguistic categories in the context. Abulhawa is a Palestinian-American writer. She is known for her very popular novel Mornings in Jenin. Now, her another great work emerged titled The Blue between Sky and Water. She was brought up in an asylum and went to America at the age of thirteen due to certain reasons. She is also a human activist. She worked for the welfare of humanity and founded an NGO "Playgrounds for Palestine" which works for the betterment of children. Her novel Mornings in Jenin became very popular as it was translated into 23 languages. The Blue between Sky and Water is her latest novel which was published in 2015. According to Crystal and Davy (1997), languages cannot be examined separately. It is because languages should not be regarded as a homogenous entity rather it is combinations of different varieties that millions of people in the world speak. Generally, all these people represent different varieties and according to linguists, these varieties are called styles. On one hand, all these varieties are different from each other to a large extent, but on the other hand, they all have much more in common, as these are the varieties of one language such as English. For instance, one can easily see the differences between spoken and written forms of the language.

Arab-American literature contains works of the Arab settlers in America. This literature started in the late $19^{\text {th }}$ century when the Arab groups from the Ottoman Empire migrated to America. Arab-American literature comprises of three separate phases with different themes, styles, and approaches as that to the Arab culture. In general, literature from the early phases shows an amalgam of Arab and American society. The second phase shows the upbringing of Palestinian American society. As a traditional literature, early Arab-American literature is not accessible to Arab

* BZ University Bahadur Campus Layyah Email: zahoor_linguist@bzu.edu.pk

** M.Phil Linguistics Scholar, ISP Multan Email: $m$ ajmal08@yahoo.com

*** University of Lahore Email: muhammad.ajmal2@ell.uol.edu.pk 
generations without prior knowledge of Arab culture. Ziltener and Kunzler (2013) observed that the main impact of colonialism is the drain of wealth, exploitation of natural resources and it became a paradise for the civil servants of colonizers with high salaries and they also ruined the psychology of colonized people. They further said that another common issue throughout the colonies was the ethnolinguistic and religious. Olp (2018) noticed that colonizers introduced their education system in the colonized areas and the main aim of this educational system was to demolish the indigenous ideology and identity. Thamarana (2015) points out that the most famous book Orientalism by Said is the overview of western writers' opinion about the eastern culture under the term 'post-colonial' studies. Several notable writers like Fanon, Achebe, Boland, Ondaajte, Kincaid, Illende, Coetzee, and Walcott were post-colonial writers. Their famous works describe the relationship between the oppressors and the oppressed like Disgrace (1990), Things Fall Apart (1958), Midnight Children (1981), English Patient (1992), and The Waiting for the Barbarians (1990). The Blue between Sky and Water centers on the sufferings of the Baraka family, forced to leave their idyllic village of Beit Daras in 1948 for a refugee camp near Gaza's southern shores. After that, the family scatters. Some remain in the camp, where the majority of the novel takes place, while others immigrate to the US. But this is not only a story about displacement. It takes in love, hatred, sex, rape, survival, death, loss, and belonging. It is full of celebratory dances, partying on the beach, mourning, fear, mysteries, dirty jokes, and national heroism.

The researcher chooses the latest novel of the Palestinian-American writer Abulhawa. Palestinian-American literature is a new genre in English literature. It is a new form of postcolonial literature which specifies the historical Palestine. The Palestinian territory is considered an open-air jail as Israel does not permit them to trade with other countries even with neighborhood Arabic countries. So they have no external links to raise their voice and are detained in the open air.

\section{Literature Review}

According to Olaniyi (2018), Stylistics is concerned with the diversity of language and styles which could be used to produce different texts, whether written or spoken, monologue or dialogue, formal or informal and scientific or religious. Crystal and Davy as cited in Olaniyi (2018) discuss the primary objective of stylistics is to evaluate language practices to recognize characteristics limited to that social context. Leech (2007) outlined the concept of stylistics, essentially characterized as the (etymological) investigation of style, is once in a while embraced for the good of its own, as an activity in depicting what use is made of language. We typically study style since we need to clarify something, and as a rule, scholarly stylistics has, verifiably or unequivocally, the objective of clarifying the connection among language and imaginative capacity (Devi, 2015). The word postcolonial stylistics seems to be a linguistic study of post-colonial literature. The stylistic features of postcolonial literature seem to consider for, exclusive study, in order not to define them, for two motives, as per overall principles and stylistic values. The writer of the colonized nations, one, has generated a literature which has both the overtly linguistic and covertly political. Therefore, the significance of literary stylistics seems justified and essential (Sriraman, 2012).

The word postcolonial emerged as substitutes in Ashcroft, Griffith, and Tiffin's (2002) texts for the very first time in the mid-1980s in the research journals. It became a part of scholarly and popular discourses by the 1990s. It has a diversity of themes such as nationalism, post-modernism, representationalism, opposition, ethnicity, and feminism. It addressed the following issues universality, distinctions, nationalism, post-modernism, representationalism, opposition, ethnicity, feminism, language, history, education, production, and place. This phenomenon arises from the frustrations of the natives and their direct, personal, and cultural conflict with that of the conquerors' culture. It also manifests fears, hopes, and dreams of their future and ethnic identities. Postcolonial literature came into being as a voice for the impotent and the poorest members of the world. Postcolonial theory works with the reading and writing of the literature published in the colonial nations of the former or presently the colonized nations. It discusses how the literatures of the colonizers distort and twist the truth. It focuses especially on how literatures by the colonizing cultures distort experience and truth. The inferiority of the colonized is revealed through their literature and they articulate their identity and reclaim their past against the unavoidable otherness (Ahmed \& AL-Saidi, 2014).

In 1950 the seminal texts of post colonialism were published. In 1950 the AiméCésaire'sDiscourssur le colonialism and two other works, 'Black Skin', 'White Masks' by Fanon 
were published. And in 1958, Things Fall Apart by Achebe was published. After them, the pleasures of Exile of Lamming and The Wretched of the Earth of Fanon were brought forth in 1960 and 1961 (Habib, 2005). A French psychiatrist Fanon analyzed the influence of non-human behavior of colonizers in his famous book The Wretched of the Earth (1961). The first edition of this book was published in French Language and then in the English language because of its importance in colonial theories. From a historical perspective, ancient Palestine had been renowned as the birthplace of prophets. Jews ruled over Palestine between 1000-586 BCE around 400 years. The Muslims governed Palestine from 617 to 1917 CE. The Muslim period was around about twelve centuries. During the Muslim period, the Christians attacked Palestine and governed it from 1099 to 1187. ${ }^{1}$ Palestine is a holy land for the Jews, Christians, and Muslims. Said (1976) noticed that during the era of the Ottoman Empire the status of Palestine as a province did not harm its identity and ethnicity. Said stated in 1822 that the maximum population of the Jews in Palestine was around 24,000. This figure is less than 10 percent of the total population ${ }^{2}$. Said (1978) wrote that before the invasion of the British, occupied territory was divided into two parts. The southern area was governed by the Ottoman Empire and the northern areas of Nablus and Acre were ruled by Beirut. In 1880, the Palestinian population was divided into the following religious groups: the majority was Sunni Muslims along with a notable amount of Christian community, Druze, and Shitte Muslims. The mother tongue of all these above-stated groups was Arabic (Al-wadaf \& Omer, 2011).

Nakba (1948) is the most important incident in the current history of Palestine. The literal meaning of Nakba is 'catastrophe', 'cataclysm', and 'disaster'. So, the Palestinian literature is also divided into pre-Nakba and post-Nakba literature. The present study is associated with post-Nakba literature but its genre is Palestinian-American. The Arabic literature created after Nakba consists of love for homeland and resistance. LughodandSa'di (as quoted in Alenzi 2015) states that the war of 1948 became the reason for the foundation of Israel and its consequences are destructive for the Palestinians. They further said that $80 \%$ of the Palestinians became refugees and the rest around 60,000 to 156,000 came under direct control of Israel. Figures show that it is ethical cleansing of the Palestinians. Arab Palestine had disappeared from the map of the world and Jewish Israel was founded. Said (1978) opined on Nakba in these words "the great dispossession of Palestine". After Nakba (1948), Naksa took place in 1967. Arab countries were united for the freedom of Palestine under the movement which is called Pan Arabism but after the six-day war, they were defeated. Barahmeh (2012) observed that the dream of a united Arab was destroyed as the result of six days of war and a wide area of Palestinian territory was gone into the control of Jews. Israel occupied West Bank and developed around 160 settlements. Palestine experienced massive political, social, and literary transformations in the first half of the 20th century. The authors thought fresh literary methods necessary to demonstrate the current historical conditions and encouraged change. Palestinian Poets had seen the need to vindicate the reason for their people and their historical records to regulate the colonial threat. At this stage, the poetry in Palestine was called the poetry of resistance (Mir, 2013). According to Mir (2013), during the first half of the $20^{\text {th }}$ century, the term resistance literature emerged among the poets in Palestinian as an outcome of their eyewitness accounts to a requirement for the new literary approach to conveying political questions and endorsing change. This word in Arabic is called 'Adab-Muqawmah' by the Palestinian author Kanafani (AlWadhaf \& Omar, 2011). The efforts of the Palestinians to construct a deliberate identity through violence they had been suffering since 1948 were expressed by the poets of resistance through their verses like Darwish and Qasim. Their creative texts deal with their ideology, history, nationalism, and the role of literature in the fight for liberty as a response to the motherland's displacement and the founding of a foreign state on two-thirds of Palestine's territory. The Palestinian poets and fiction writers subsequently wrote literary works on resistance provoked by resistance. Tuqan shifted towards resistance poetry under the influence of Darwish and Qasim after the 1967 Arab-Israel war (Mir, 2013). According to Slemon (1995), "literary resistance can be seen as a form of contractual understanding between the text and the reader, one that is embedded in an experiential dimension and buttressed by a political and cultural aesthetic at work in culture" (p.7).

Israel has enforced its version of the dispute between Israel and Palestine in the West for so many years. The fact of the history of Palestine is often falsified by the US-controlled international media. Palestinian narrative was produced in Arabic Language. Because of this reason the 
Palestinian literature has fewer readerships than the Israeli Literature who has used the western languages for their narrative. Joe (2004) states that the fundamental objectives of Palestinian writings are to give a more develop Israeli model of a Palestinian counter-narrative. The utilization of a worldwide language is probably going to pass on the weight of one's history and experience to the entire globe. In such a manner and in her critique on her novel Mornings in Jenin, which is written in English language, Abulhawa feels that her story has attracted the readers of the West and convince them of the Palestinian narrative.

\section{Research Methodology}

The present study is quantitative and qualitative in nature. Silverman (2000) stated that qualitative studies focus on the comprehensive handling of phenomena. Stake (1994) furthers that qualitative studies focus on world cultures and quantitative relationships to local individuals and neighborhoods. While qualitative research relies on the clustering of quantitative data, quantitative research studies the individual cases. The researcher utilizes a variety of data analysis tools and methods for explanation and interpretations. As many approaches, many researchers can be used to perform a study utilizing a quantitative approach; it is thus hard to identify a single title (Creswell, 2010; Punch 2009; Mackey \& Gas, 2005). For data analysis of the current study, the researcher used both quantitative and qualitative approaches. The reliability and validity of the research results were ensured by a mixed-method research design (Creswell, 2010; Punch 2009; Mackey \& Gas, 2005). In mixed-method research, the researcher combined the aspects of qualitative and quantitative method of research for the broad purposes and in-depth analysis. In the last ten years, the procedures of this approach has been developed and purified to outfit a wide range of research questions (Creswell \& Clark, 2011).

The purpose of the present research is to study the text of The Blue between Sky and Water. The full text of the novel was not to be analyzed. Thus, a random sampling method has been adopted for the study of The Blue between Sky and Water. The text is selected randomly from the beginning, middle, and end. In the same way, the researcher used the most frequent nouns and adjectives for analysis which is approximately one-third of the total. The word 'corpus' originated from the Latin language which means a 'collection of texts'. Its plural is corpora. The text is collected in a digital database. Baker, Hardie and MacEnery (2006) said that "Although a corpus does not contain new information about language by using software packages which process data, we can obtain a new perspective on the familiar" (pp. 48-49). Corpus Stylistics made progress in research of the style utilizing computer-supported methodology for the evaluation of text through language gathered and inserted into corpora (Wyne, 2005). According to Biber (2011), Corpus stylistics introduced a fresh field of study for the quantitative and empirical evaluation of a literary text. For many decades, various stylistics researches of the literary language make use of computational methods of words assessment have emerged. The present research related to corpus linguistics is executed under the umbrella of corpus stylistics. The researcher used the AntFileConverter, AntConc, TagAnt, USAS, L2SCA, and CLAWS parts-of-speech tagger as a research tool.

The data of the present research is the text of Susan Abulhawa's The Blue between Sky and Water. First, the researcher conducted the corpus-based analysis with the help of four software: AntFileConverter, TagAnt, USAS online semantic tagger, and AntConc. With the help of AntFileConverter, the researcher convert the epub file to notepad.

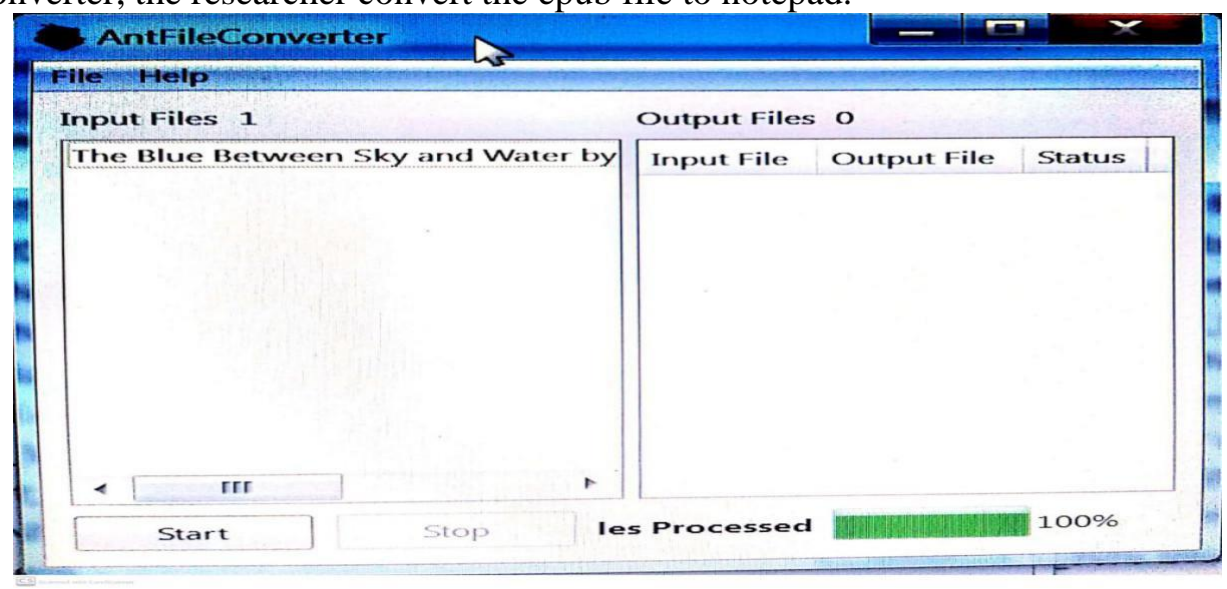


As Denscombe (2003) elaborates that "Each separate piece of the data should be identified with a unique serial number or code for reference purpose." So the researcher mentioned those lines and page numbers in which the metaphors and similes occurred. For nouns and adjectives, the researcher put the pictures of the AntConc window for relevancy. It was noted that for the economy of words, the syntactic rules deviated many times in the text as verb-less sentences and minor sentences of three words were often used by the writer. Besides, the deviation that occurs through syntax, code-switching, and figures of speech are also noted. As Gregoriou (2009) explains that deviations are essentially "violations or departures from certain linguistic norms." (p. 28). The researchers explain in the subsequent lines the purpose of this software, how they function, and how they are used for analysis.

\section{Data Analysis}

The researcher first used the TagAnt software for tagging nouns and adjectives. Then the researcher put the tagged data in AntConc for finding the nouns and adjectives in the text with the help of taggers.

\section{Lexical Categories}

The novelist used around 12920 nouns in her novel the Blue between Sky and Water. More frequent and marked nouns, 69388 concrete and 1686 abstract nouns respectively.

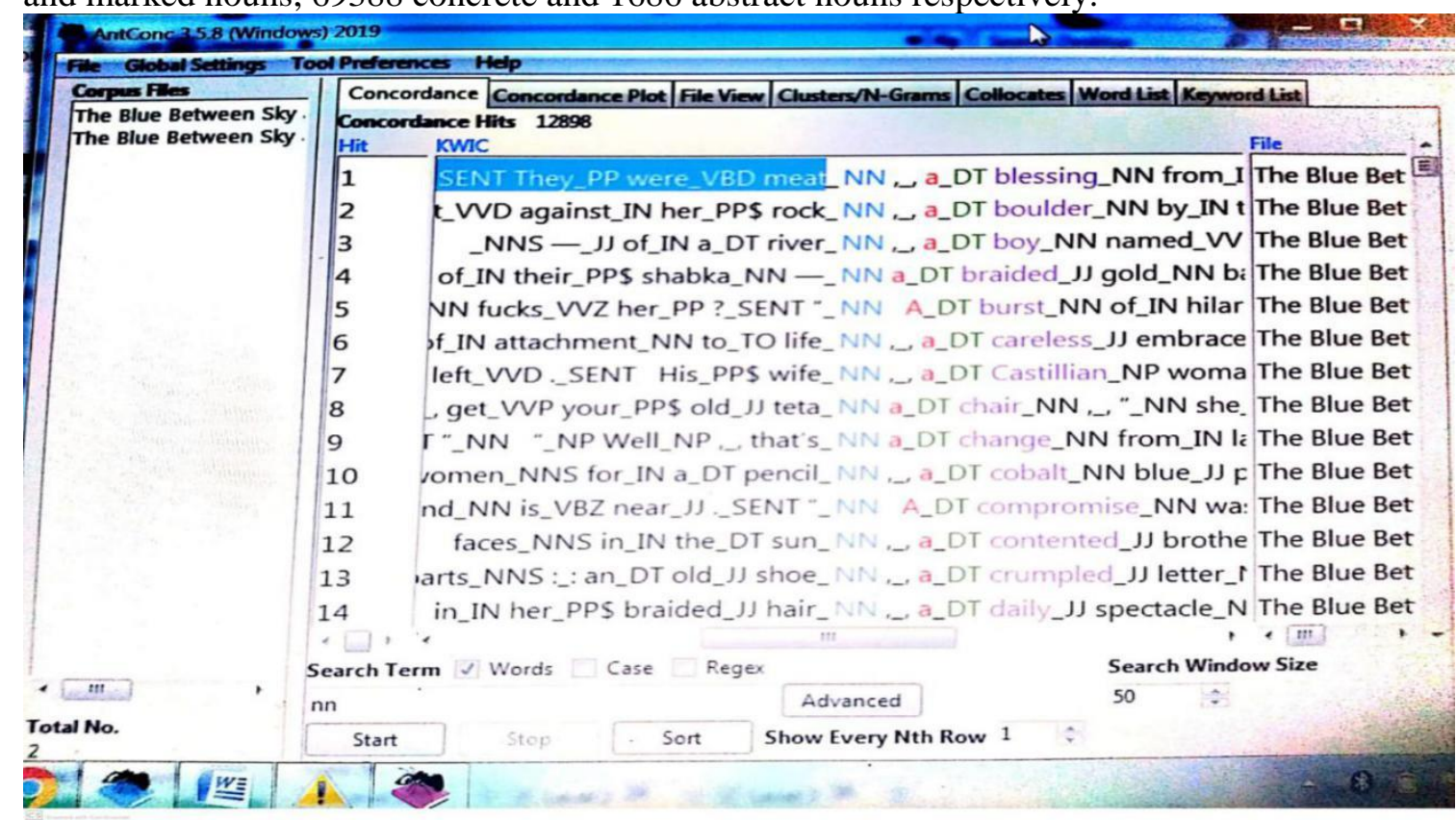

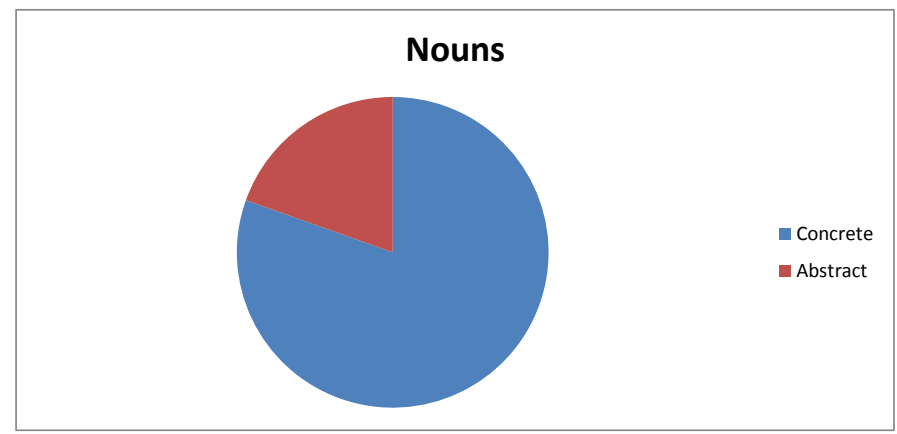

Figure 4.1 Nouns 


\section{Nouns}

The writer used the following lexical items. The novelist used around 12920 nouns in her novel the Blue between Sky and Water. More frequent and marked nouns, 6938 concrete and 1686 abstract nouns respectively. This means that the writer presented more concrete nouns than abstract nouns. She depicted concrete things like homeland. They used words as fatherless, homeless, motherless, loneliness, merciless and ruthless. These words showed that the people of Palestine received every kind of injustice and cruelty since birth.

\section{Concrete Nouns}

Among concrete nouns, the most frequently occurring category was personal names such as the Arabic and the Quranic names. The most frequent Arabic name is Nur. Nur is the protagonist so this name has been used 728 times.

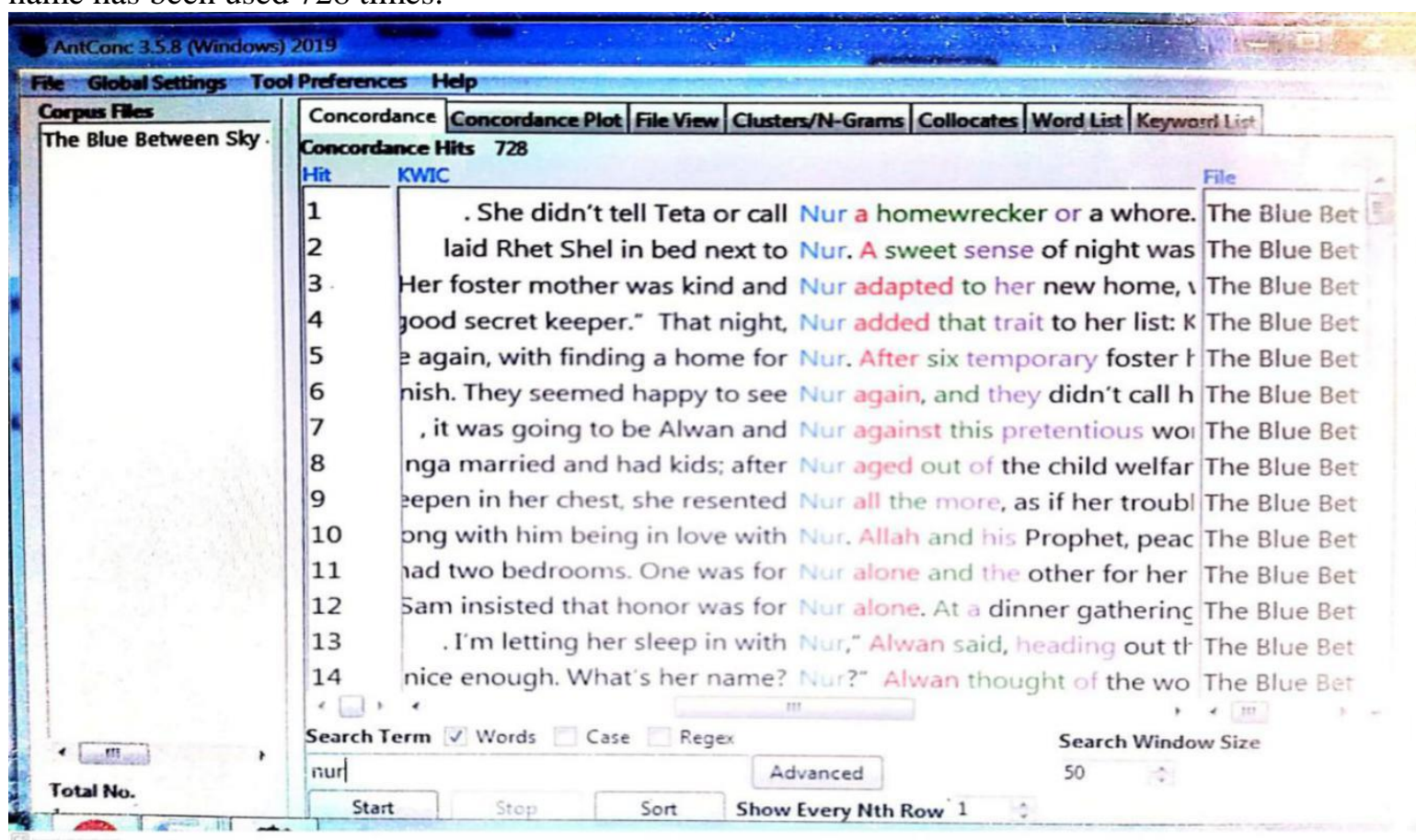

Another most frequent name is Nazmiyeh which occurred 502 times. Nazmiyeh is the central character of Nur's family. Rhet Shel was found 219 times in this novel which is a mixture of the Arabic and the American names.

\begin{tabular}{|ll|}
\hline Concrete Nouns & \\
\hline & \\
& $=$ Personal Names \\
& $=$ Collective Nouns \\
& $=$ Geographical Terms \\
& $=$ Food items \\
& $=$ Body parts \\
& $=$ Common Nouns \\
& \\
\hline
\end{tabular}

Figure 4.2 
The American rather than Arabic names were traced 301 times in this novel. Another most frequently occurring name Nzinga was traced 119 times. Nzinga is the friend of Nur who helps him like a caretaker. Next to the concrete nouns, Common nouns were found 1797 times. The most frequently occurring common noun is home was found 152 times. Beekeeper was found 69 times. Noun related to the human body was found 817 times. In body parts, the most frequently occurring noun is Eyes used 187 times, and the word Eye as singular used 32 times. Another category was Collective nouns traced through the analysis as they were 602 times. The most frequently occurring collective noun is "Family" which was found 175 times. The nouns related to geographical terms were 402. Under the category of geographical terms, the most frequently occurring word was Gaza was found 136 times. The second most frequent occurring geographical term was Beit Daras found 85 times. Beit Daras was the native city of Nur's family.

\section{Abstract Nouns}

The use of abstract nouns depicts the relation of ideology to the Palestinian world. If we further classify the abstract nouns then we get the result that the most frequent abstract noun used in this novel is related to processes that are 746. After that abstract nouns which are related to the moral quality is used 241 times and the nouns related to perception were 338 times.

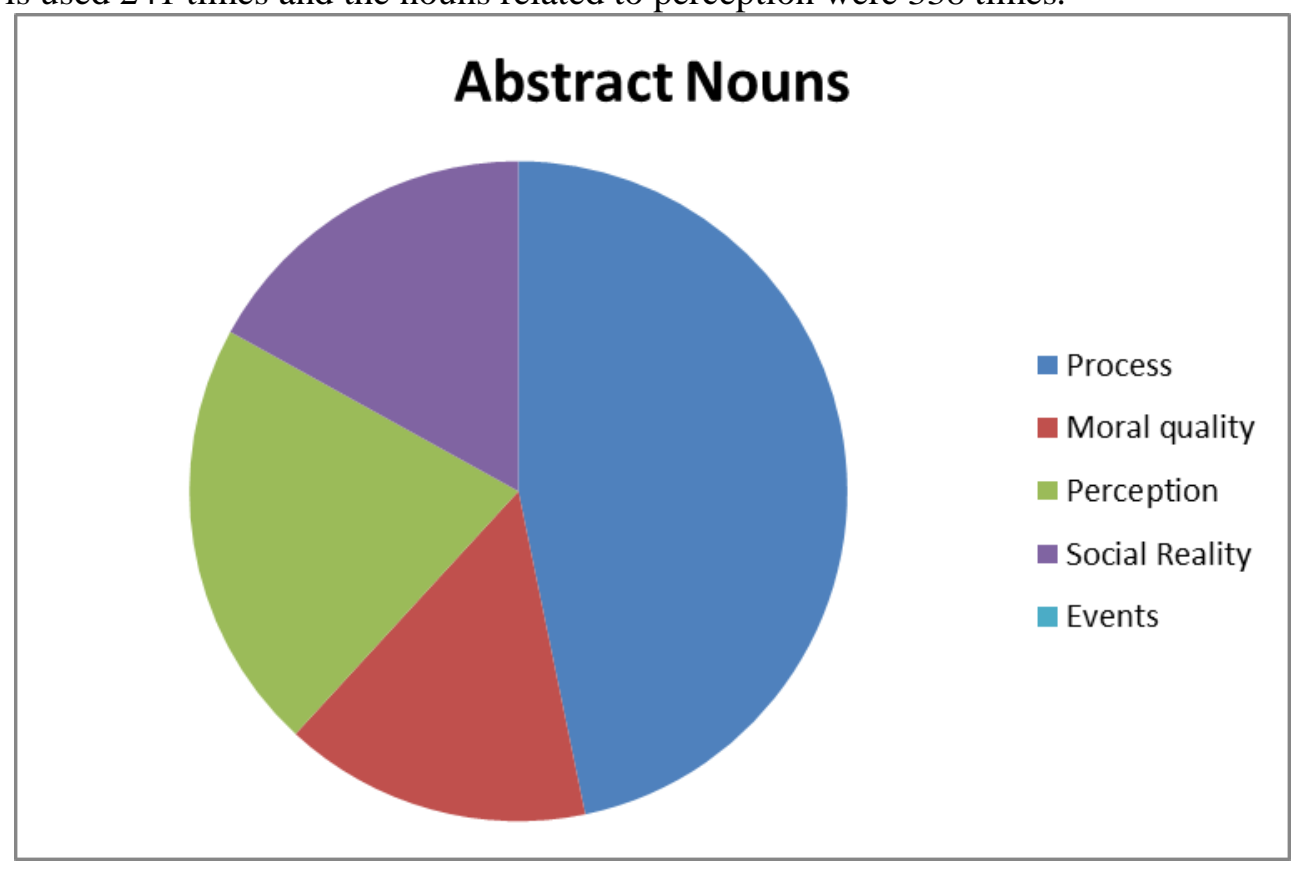

Figure 4.3

Abstract Nouns that were related to social realities were 271 and the nouns related to events were around 38. Time is the most frequent abstract noun used in this novel. The word time is used 165 times. The second use of time is marked because it depicts another world in which the Palestinian people achieve pleasure and free themselves from the hardships of life which they are facing." It wasn't long after that when I went into the quiet blue that place without time, where I could soak up all the juices of life and let them run through me like a river."(Abulhawa, pp. 2-3). Another occasion where the writer uses time to the non-human ability of one of the characters named Mariam as verified in concordance hit number 5. The word thought is used 66 times in this novel under the category of process in abstract nouns. The word memory was found 28 times, the word dreams used 20 times. The word hope 15 times and the word calm were traced 13 times. The more frequent words traced under the category of perception are abstract nouns. For instance, fear was found 25 times, anger and joy 12 times, humiliation 11 times, shame 11 times, and mind 11 times. Abstract nouns that are related to the moral quality are used 241 times such as the most frequently occurring word Hajje was used 208 times. Abstract nouns which are related to events are just 38 such as birthday and marriage is used 11, 11 times and funeral 2 times. Abstract nouns that are related to social realities are 271 in which the word life is more frequent occurring 101 times. Other examples are the following: death used 24 times, a die 18 times, mercy 16, 16 times, trust 14 times, freedom 12, 12 times respectively. 


\section{Adjective Types}

The most frequent adjectives were physical adjectives which were 475, the second most frequent occurring adjective were evaluative adjectives traced 242 times. The color adjectives found 204 times. Emotive adjectives were 102 in number. Psychological adjectives were 89. Visual adjectives were 47 , referential adjectives 208 and auditory adjectives were traced 23 times respectively.

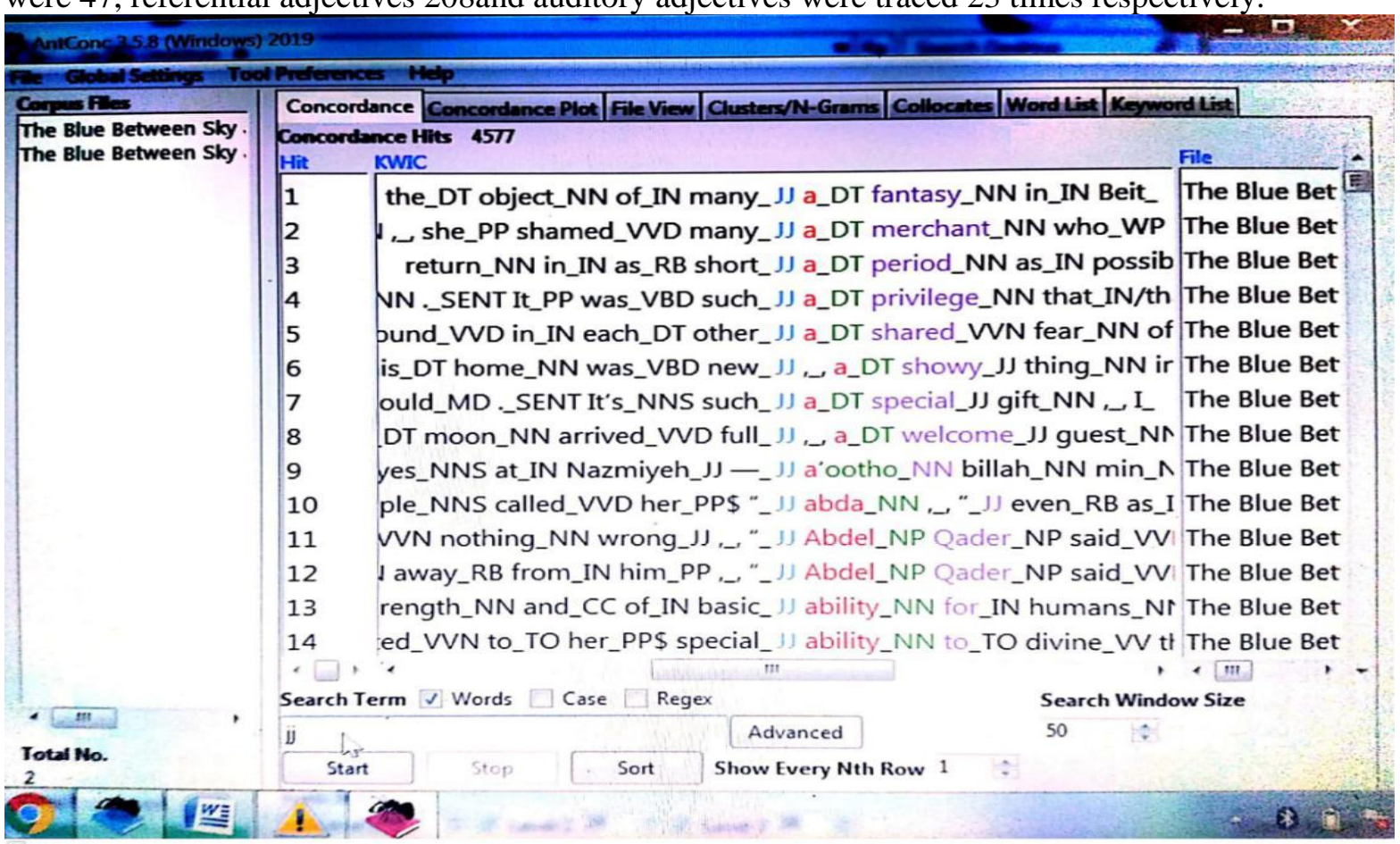

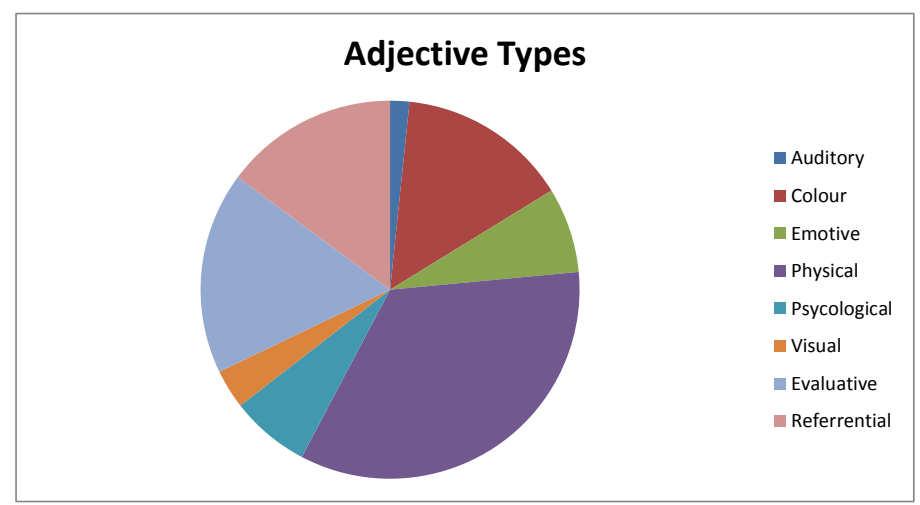

Figure 4.4

The writer used around 12920 nouns in her novel. The researcher traced out 6288 concrete and 1686 abstract nouns respectively. The writer extensively used concrete nouns which showed her inner turmoil for homeland. It means that this literary piece is a statement of life problems and has an important aim to get freedom from Israel. They make it an open jail for the detained Palestinians since 1948. The most frequent common concrete nouns were home, house, room, river, bed, school, doctor, sea, sun, ocean, shore, earth, and sky. The most frequently occurring common nouns related to the human body were body, eyes, heart, hand, and belly. The most frequently occurring nouns related 
to geography were Gaza and Beit Daras. The most frequent proper nouns were Nur who was the protagonist than Nazmiyeh, Alwan, Khaled, Rhet Shel, Sulayman and Mariam occurred. The most frequent occurring collective noun was family, children, and people.

The use of concrete nouns depicts the writer's eagerness for homeland and also shows that this novel is not art for art's sake or recreational purposes. The nouns home and house are also more frequently occurring nouns for example, "hungry for home" (Abulhawa, 2015 p. 78). The noun shoe represents the value of natives in the occupied Palestine who faced discrimination, hatred and Israeli ignored their identity like an old shoe. Concrete Nouns Sea, river, ocean, and shore showed the Israel occupied their water resources. The Israelis are one-sixth of the Palestinians but they use the same amount of water as the Palestinians. For example, "The elation at sea was suddenly muted as Israeli naval vessels sped toward fleet" (Abulhawa, 2015 p. 88). The most frequently occurring noun related to body was eyes which was found 187 times e.g. "watchful eyes" (Abulhawa, p. 01). Mariam was a small sister of Nazmiyeh who blessed was with two different eyes and she could see more colors with these eyes and make predictions. Nur is the protagonist who has also Mariam's eyes. The noun belly was used as marked one on many occasions. It represents the pain of hunger, lack of food in refugee camps and also depicts the sexual harassment of the Palestinian girls. The nouns referred to Gaza and BeitDaras also depict the inner turmoil of the writer for the sake of freedom of her historical Palestine from the claws of Israel. BeitDaras faced a massacre in 1948 and was wiped off from the map of Palestine. Gaza is still in trouble. The personal noun "RhetShel" originated from an amalgam of the Arabic and English language names. "Rachel Corrie" was an American activist and murdered by the Israeli bulldozer because she tried to save the Palestinian home (Abulhawa, p. 91). The incident takes place at Rafah refugee camp near the Gaza Strip and Egypt border. Old Rachel Corrie who was 23 murdered on 16 March, 2003. The use of the most frequently occurring collective noun family describes the displacement dilemma that because of migration and bombardment, families of the Palestinians dispersed and faced identity issues. Another collective noun children demonstrate the physical, psychological and educational issues of children. The writer also works for children and has an organization of child which makes playgrounds in Palestine. Abstract nouns were approximately one-fourth of the traced concrete nouns. The researcher traced out the 1634 abstract nouns in which the most frequently occurring category was related to process than perception and the third was associated with social reality. The abstract nouns also describe the struggle of the Palestinians for the freedom of homeland and also depict the writers' state of mind to portray the core of the issue of the Palestinians through their words and no doubt she succeeded.

The most frequently occurring adjectives were physical adjectives around 475 in which the most frequently occurring adjective was old. Nur's mother treated her badly and neglected Nur at every important occasion. She showed that Nur was a burden on her. Santiago, a relative of Nur's mother raised a voice against the cruel activity of Nur's mother For example, he said about Nur "she is not an old shoe" (Abulhawa, 2015 p. 63). The dilemma of displaced people is that they always live in the past. Mostly the Palestinians migrated from rural Palestine. Now they live in the Gaza Strip, West Bank, or refugee camps near Arab countries. But they love their past and their writings demonstrate the nostalgic element. The second most frequently occurring category was evaluative adjectives which were found around 242 in the text. The adjectives related to color were traced 209 times. The frequent use of color adjectives describes the psychological condition of the Palestinian people whose life is colorless. The writer also uses colors in figures of speech. The deprived people try to make their ideal world colorful. Mostly used color was blue which was also used in the title of the novel The Blue between Sky and Water. The novelist said that blue color shows sincerity and contentment (Abulhawa, 2015 p. 6). Through this color, she tells their readers that the Palestinians are sincere with their aim and commitment. Nur lived with her mother but was deprived of every good thing. The writer depict her hunger for dress and other items through color "striped dress with a red sash" (Abulhawa, 2015 p. 57), and red word was also used with an organization who helps the Palestinians e.g. 'Red Cross' (Abulhawa, p. 75).

\section{Conclusion}

The writer aimed to portray the crisis of Palestine and a representation of her culture and language. Israel raised his voice with power and convinced the world powers on their agenda in the absence of Palestinian literature. So, with the help of the English language Arab writers boost their slogans and told the world that the Israeli forces crushed human rights since Nakba (1948 Palestinian Israel war) 
and Naksa (1967 Arab Israel War). The frequent use of concrete nouns showed that the main purpose of the writer was not abstract things rather she wanted a peaceful homeland for the Palestinians.

\section{References}

Anthony, L. (2015). TagAnt (Version 1.1.0) [Computer Software]. Tokyo, Japan: Waseda University. Retrieved from: https://www.laurenceanthony.net/software

Anthony, L. (2017). AntFileConverter (Version 1.2.1) [Computer Software]. Tokyo, Japan: Waseda University. Retrieved from: https://www.laurenceanthony.net/software

Anthony, L. (2019). AntConc (Version 3.5.8) [Computer Software]. Tokyo, Japan: Waseda University. Retrieved from https://www.laurenceanthony.net/software

Ashcroft, B., Griffiths, G., \& Tiffin, H. (1989). The empire writes back. London: Routledge.

Ahmed, A., \& Al-Saidi, H. (2014). Post-colonialism literature the concept of self and the other in Coetzee's waiting for the barbarians: An analytical approach. Journal of Language Teaching and Research, 5(1), 95-105.

Alenzi, S. (2015). An analysis of formulation of post-colonial identity in the word of Edward W.Said and Mahmoud Darwish: A thematic and stylistic analytical approach (Doctoral dissertation). University of Manchester, England, UK.

Al-Wadhaf, Y., \& Omar, N. (2011). Narrating the nation and its other: The emergence of Palestine in the postcolonial Arabic novel. The Southeast Asian Journal of English Language Studies, 17(Special Issue), 109-119.

Barahmeh, Y. (2012). The poetry of Mahmoud Darwish: A study of the three development phases of his poetic career. London: Lambert.

Baker, P., Hardie, A., \& Mcenery, T. (2006). A glossary of corpus linguistics. Edinburgh: Edinburgh University Press.

Biber, D. (2011). Corpus linguistics and the study of literature, back to the future. Scientific Study of Literature, 1(1), 15-23. Doi: https://doi.org/10.1075/ssol.1.1.02bib

Crystal, D., \& Davy, D. (1997). Investigating English style. Harlow: Longman.

Creswell, J., \& Clark, V. (2011). Designing and conducting mixed methods research. Washington DC, America: SAGE.

Devi, D. (2015). Stylistic analysis: A selected passage from Arundhati Roy's The God of Small Things. Research Journal of English Language and Literature, 3(3), 547-551.

Denscombe, M. (2014). The Good Research Guide ( $5^{\text {th }}$ ed.). England: U.K. Open University Press.

Habib, M. (2005). A History of Literary Criticism: From Plato to the present. Oxford, United Kingdom: Blackwell publishing.

Leech, G., \& Short, M. (2007). Style in Fiction: A Linguistic Introduction to English Fictional Prose $\left(2^{\text {nd }}\right.$ Ed.). London: Longman.

Mir, S. (2013). Palestinian literature: Occupation and exile. Pluto Journals, 35(2).pp. 110-129.DOI: 10.13169/arabstudquar.35.2.0110. Retrieved from: http://www.jstor.org/stable/10.13169/ arabstudquar.35.2.0110? seq=1\&cid=pdf-reference\#references_tab_contents

Olaniyi, T. (2018). Language, Style, and Meaning in transaction messages of selected Banks in Nigeria (Bachelor Thesis). University of Ibadan, Ibadan, Nigeria.

Opl, M. (2018). How Colonization Impacts Identity through the Generations: A Closer Look at Historical Trauma and Education (A Doctoral Dissertation, University of Denver, Colorado, United States). Retrieved from: https://digitalcommons.du.edu/cgi/viewcontent.cgi?article= 2487\& context=etd

Said, E. (1976). The question of Palestine. New York, NY: Vintage Books.

Said, E. (1978). Orientalism. New York, NY: Vintage Books.

Silverman, D. (2000). Doing Qualitative Research: A Practical Handbook (ed.). London: Sage.

Slemon, S. (1990). Unsettling the Empire: Resistance theory for the second world. In B. Ashcroft, G. Griffiths \& H. Tiffin (Ed.) ( $2^{\text {nd }}$ ed., p. 104-110). The post-colonial studies reader. London: Routledge.

Sriraman. (2012). Stylistics. In Lavanya (Ed.), Block III. PGDTE course material. EFLU, Hyderabad.

Stake, R.E. (1995). Case studies, In N.K. Denzin and Y.S. Lincoln (Eds) Handbook of Qualitative Research. London: Sage. 
Thamarana, S. (2015). Significance of Studying Postcolonial Literature and its Relevance. Research Journal of English Language and Literature, 3(3), 537-541.

Wyne, M. (2005). Developing Linguistic Corpora: A guide to good practice. Oxford: Oxbow Books.

Ziltener, P. \& Kunzler, D. (2013). Impacts of Colonialism - A Research Survey. Journal of WorldSystems Research, 19(2), 290-311 